\title{
CITIZEN SCIENCE IN AUSTRIA
}

\section{by Daniel Dörler and Florian Heigl}

Abstract: Citizen Science, the active involvement of lay people without any academic education in the project specific scientific process, has experienced a massive increase in academic fields and projects in the last years. This active involvement can be designed in many different ways, which is often project and context specific. The popularity of citizen science goes hand in hand with the discussion about open science, and in fact both concepts are deeply connected with each other in many ways. Whereas in open science lay people don't have to be involved in a project necessarily, citizen science often uses open science methods and tools to make this active involvement possible. In this text, the authors will give a short introduction to citizen science, its connections to open science, and the developments of citizen science in Austria in the last years and in the future.

Keywords: public participation; open science; network; involvement

\section{CITIZEN SCIENCE IN ÖSTERREICH}

Zusammenfassung: Citizen Science, die aktive Einbeziehung von Laien ohne akademische Ausbildung im projektspezifischen wissenschaftlichen Prozess, hat in den letzten Jahren eine massive Zunahme innerhalb wissenschaftlicher Fachdisziplinen und Projekten erfahren. Diese aktive Beteiligung kann auf viele verschiedene Arten gestaltet werden, die oft projekt- und kontextspezifisch sind. Die Popularität der Citizen Science geht Hand in Hand mit der Diskussion über Open Science, und tatsächlich sind beide Konzepte in vielerlei Hinsicht eng miteinander verbunden. Während bei Open Science Laien nicht unbedingt in ein Projekt einbezogen werden müssen, nutzt die Citizen Science häufig Methoden und Werkzeuge der Open Science, um diese aktive Einbeziehung zu ermöglichen. In diesem Beitrag geben die Autoren eine kurze Einführung in die Citizen Science, ihre Verbindungen zur Open Science und die Entwicklungen der Citizen Science in Österreich in den letzten Jahren und in der Zukunft.

Schlagwörter: Öffentlichkeitsbeteiligung; Open Science; Netzwerk; Einbindung

DOI: https://doi.org/10.31263/voebm.v72i2.2835

(C) Daniel Dörler, Florian Heigl

Dieses Werk ist lizenziert unter einer

Creative-Commons-Lizenz Namensnennung 4.0 International 


\section{Contents}

1. Introduction

2. What is Citizen Science?

3. Citizen Science and Open Science

4. Citizen Science in Austria

5. The future of citizen science in Austria

\section{Introduction}

Researchers have been collaborating with lay people in scientific endeavours for a long time. In recent years, the term "citizen science" has been attributed to most of these projects, covering a diverse range of citizen involvement in scientific research [1-3]. A general agreement of what citizen science is, however, is not existing $[1,4]$. Several approaches have tried to frame citizen science in the last years $[2,3,5]$. Citizen science and open science share a common claim to openness in the scientific process and have a lot in common [6,7]. The main difference lies in the involvement of citizens, that is key for citizen science, but is no prerequisite for open science. In Austria, citizen science has been framed mainly by the community platform Österreich forscht (www.citizen-science.at) and the Citizen Science Network Austria in recent years, that connects citizen science actors, displays citizen science projects to an interested public and aims to foster and secure the quality of citizen science research [8]. Founded and coordinated by the authors of this article it evolved from a volunteer effort to a fully established community supported by the University of Natural Resources and Life Sciences, Vienna, in just five years. This sets an example for many similar initiatives all over Europe and makes Austria an important player in the citizen science research landscape also for the future.

\section{What is Citizen Science?}

Citizen science has become a buzzword in the scientific community in recent years. However, if you ask an ecologist, a sociologist and a scientist from the humanities what citizen science is, you will get three different answers. The least common denominator all three would probably agree on is that in citizen science lay people are actively involved in the scientific process $[9,10]$. How this involvement is shaped in particular is very con- 
text-specific, and therefore often depending on the academic discipline of the citizen science project. In ecology, lay people are often involved in data collection or analysis [11-14]. In sociology, the involvement is often realized in the whole scientific process, so citizen scientists help formulate the research question, shape the design of a project, collect and analyze data and are even contributing in the publication of the results $[15,16]$. In humanities, the involvement is often located somewhere between the ecological and the sociological degree of involvement [17-19]. An overall definition of citizen science is still lacking, but first attempts have been made by different stakeholders $[1,4,20,21]$. Since citizen science is very diverse, such a definition suiting all kinds of academic disciplines is not easy to find. Therefore, most people studying citizen science have focused on finding a typology to somehow grasp this diversity. Probably the most well-known typology was published in 2013 by Muki Haklay [2]. He defined four levels of citizen science based on the level of participation of lay people in a given project:

- The first level he called crowdsourcing, where people act as sensors or provide resources. Many ecology-based projects would fall into this category, such as "Stunde der Wintervögel" (https://www.citizen-science.at/projekte/stunde-der-wintervoegel), "Project Roadkill" (https://www.citizen-science.at/projekte/roadkill) or "StadtWildTiere" (https://www.citizen-science.at/projekte/stadtwildtiere).

- The second level, called distributed intelligence, describes projects, where people act as basic interpreters, e.g. to classify pictures or analyse short videos, such as "NestCams" (https://www.citizen-science.at/component/k2/item/435-nestcams).

- In the third level, participatory science, citizen scientists are involved in forming the research question and collecting data. An example for this type of citizen science project would be "Reden Sie mit!" (https://www.citizen-science.at/projekte/reden-sie-mit).

- The fourth level, called extreme citizen science, involves projects where lay people ask the research question, collect data and analyse data together with scientists. In Austria, project "GenTeam" (https://www.citizen-science.at/projekte/genteam) as a citizen-led project would be a great example for this kind of citizen science project.

As simple and concise this typology is, it also has a downside, even though unintended by Muki Haklay: it puts a hierarchy of participation over citizen science, where extreme citizen science projects seem to be the best 
projects, and crowdsourcing projects are the simplest, ignoring the fact, that some people are content by contributing to a crowdsourcing project and don't want to be involved in the whole project [22]. Therefore, following typologies, although also based on the type of participation of lay people in the projects, were avoiding any hierarchization. They ordered the different types of citizen science projects in a circle next to each other, such as Sanz et al. (2014) in their "White Paper on Citizen Science for Europe" [3] (see also Fig. 1). They defined seven types of citizen science projects, adding (I) serious games, where people collect data or find solutions for problems by playing computer games, (II) grassroot activities, where the whole scientific project is sometimes done without any professional scientist involved, and splitting distributed intelligence projects in two distinct types of citizen science projects, called (III) data collection and (IV) analyses tasks.

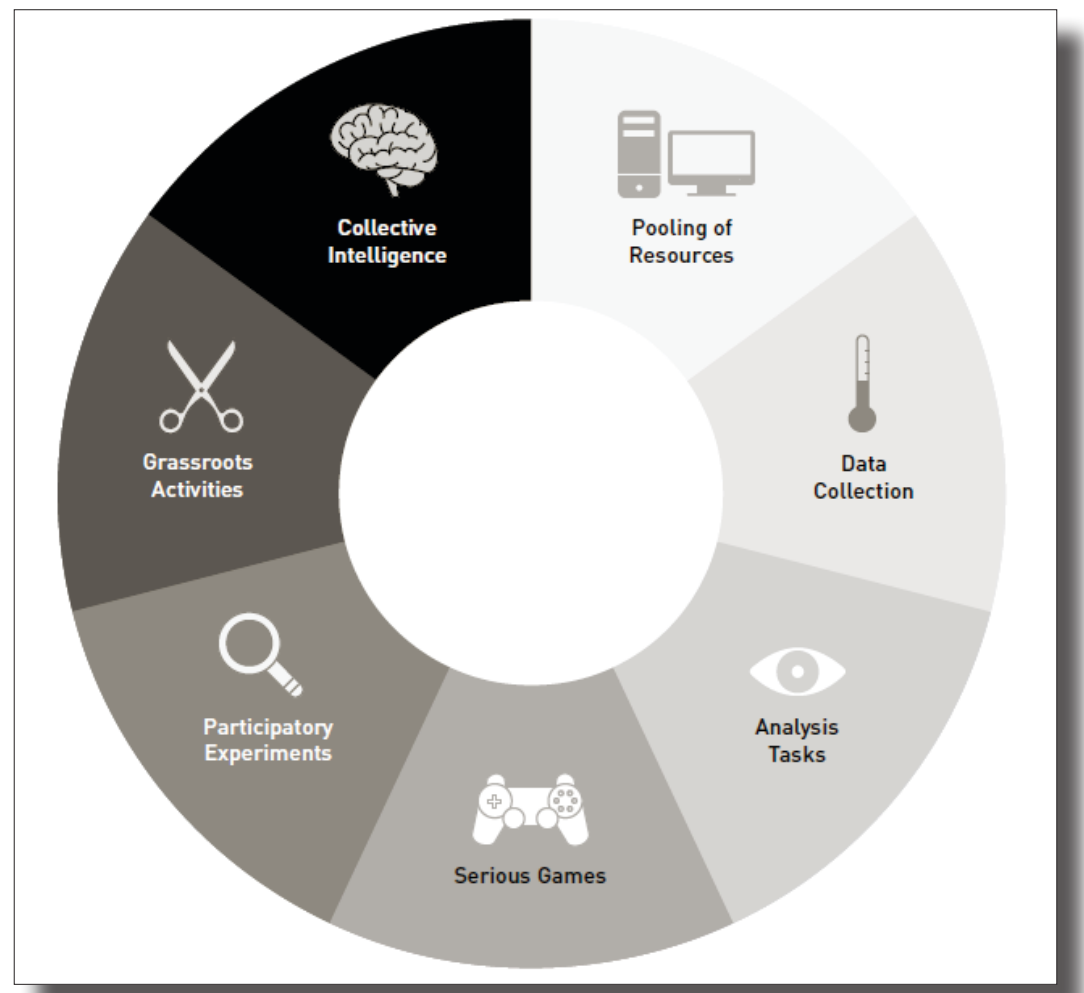

Fig. 1: Models of citizen engagement in science [3]. Different types of citizen science projects are ordered in a circle next to each other, avoiding an unintended hierarchy. 


\section{Citizen Science and Open Science}

Citizen science, as well as open science, has the aim to open the scientific process for people outside academia [6,7]. Open science was defined very recently as "transparent and accessible knowledge that is shared and developed through collaborative networks" [23]. Whereas in open science lay people don't necessarily have to be personally involved in a project, it is the key feature of any citizen science project. However, both concepts have a lot in common. Both strive to make research more transparent and comprehensible. Open access publications are of great importance for open science as well as citizen science. Citizen science sometimes even goes a step further, making the results also available in generally understandable reports in the mother tongue of project participants, since academic publications are usually written in English and in technical language. In open science, open data are currently one of the main goals, making research data findable, accessible, inter-operable and re-usable [24]. Also, the citizen science community agrees to share data with the general public, since lay people spend their precious free time to collect the data in most projects, and also to potentially spark new projects by other people. Additionally, the open science community advocates the use of open source tools, and these tools are also often used in citizen science projects. One example for an often used open source tool in citizen science projects is Open Street Map. However, some projects (especially app-based projects) also use commercial products, since they have to compete with other commercial apps for attention on the smartphones of their participants. They have to be as attractive, intuitive and enjoyable as other popular apps, such as social media apps. Such app-based projects mostly rely on software companies to design apps that are beautiful and enjoyable for the participants, and at the same time collect scientifically sound data. In Austria the company Spotteron (www. spotteron.net) has specialized for these kind of projects, and several popular citizen science projects such as Project Roadkill, Tea Bag Index or Naturkalender are relying on Spotterons design and programming framework.

\section{Citizen Science in Austria}

In Austria, the method of citizen science has been around for a long time. The oldest project is probably from the Austrian national meteorological service (Zentralanstalt für Meteorologie und Geodynamik, ZAMG) in Vienna that collects phenological data together with lay people since 1851 
(http://www.phenowatch.at/). However, a systematic inventorization of the active involvement of lay people in scientific research is only possible since 2014, when we, the authors of this article, founded the citizen science platform Österreich forscht (which means "Austria does research") [8]. The goals of the platform are to connect citizen science actors across Austria, to secure and raise quality of citizen science projects and to display existing citizen science projects to an interested public, regardless of institutional background or academic discipline [25]. This can be illustrated with the project Roadkill (https://www.citizen-science.at/projekte/roadkill). It was founded in parallel of the platform by one of the authors of this article. In the last years project Roadkill became one of Austria's most famous citizen science projects, and gained additional visibility through the listing on Österreich forscht. Almost 11.000 views on the project's profile on Österreich forscht prove the positive effect of a listing. Through the connection with other citizen science actors on Österreich forscht it was possible to cooperate with other projects such as Herpetofauna (https://www.citizen-science. at/component/k2/item/221-herpetofauna), thus improving the project through additional expertise in identifying amphibian and reptile roadkills. The adaptation of the project to the community quality criteria (see below for more detailed information) increase the quality of project Roadkill on several levels, such as transparency and data management.

In the beginning, the coordination and management of the platform was done in our free time, with no institutional backing. Soon after the launch of the platform, we organized the first Austrian Citizen Science Conference in early 2015, already displaying many different approaches of citizen science in Austria. At this time, 9 projects coming mainly from natural sciences were listed on the platform (e.g. Phenowatch by ZAMG, Stunde der Wintervögel by BirdLife Austria, GeoWiki by IIASA, Wiener Gebäudebrüter by MA22). These first pre-existing projects were actively contacted by us via e-mail and offered to be listed on Österreich forscht, to increase visibility of the projects. After the first conference, more projects joined the platform, now also coming from other academic fields, such as the humanities (e.g. ExploreAT). In 2016, the second Austrian Citizen Science Conference was still very dominated by natural sciences. However, some projects from the humanities and the social sciences also presented themselves during the conference $[25,26]$, such as BrotZeit (https://www.citizen-science.at/projekte/brotzeit). In the same year, we also got funding for one post-doc position by the University of Natural Resources and Life Sciences, Vienna, to further manage and coordinate Österreich forscht. 2017 marked a significant change in direction for Österreich forscht, mainly because of three decisions: 
- The Citizen Science Network Austria (CSNA) was founded to institutionalize the collaboration of the different institutions on Österreich forscht. All members signed a Memorandum of Understanding, stating that they are working together in the network to foster the method and quality of citizen science, to work together in different working groups, and to discuss new developments on the Austrian Citizen Science Conference.

- We founded the first working group within Österreich forscht, with the aim to formulate transparent and transdisciplinary applicable criteria that would help us as platform managers to decide whether a project applying for listing on Österreich forscht should be listed as citizen science project or not. This working group was active for one year, until the Austrian Citizen Science Conference in 2018 $[4,21,27]$.

- We decided to further open the Austrian Citizen Science Conference, first, by making an open call for sessions. The first two Austrian Citizen Science Conferences in 2015 and 2016 had preset sessions instead. The result was a massive increase in project presentations from the humanities and social sciences participating in the conference and, at a later stage, joining the platform. Second, we decided to open the conference for an interested public on a third conference day, giving people the opportunity to try out citizen science projects on the spot [28].

These three decisions led to a more inclusive, diverse and respected citizen science community in Austria, showing that numerous institutions collaborate to foster this method and to secure its quality.

In 2019, Österreich forscht and the CSNA were permanently funded by the University of Natural Resources and Life Sciences Vienna.

Today, there are more than 70 ongoing or already concluded projects from natural sciences, social sciences, humanities and arts listed on Österreich forscht. The CSNA currently has 37 members, namely universities, NGOs, museums, associations, companies and universities of applied sciences.

\section{The future of citizen science in Austria}

Due to the now permanent support provided by the University of Natural Resources and Life Sciences, Vienna, the CSNA is now recognized also 
by the international citizen science community as a stable and important partner in citizen science. The CSNA sets an example of how a citizen science network can be established from scratch, and we as founders and coordinators share our experience and knowledge with international colleagues in working groups of the European Citizen Science Association (ECSA), in the currently running COST-Action on Citizen Science and in various bilateral meetings.

In Austria, our work now focuses on spreading the know-how on citizen science from already established citizen science hubs to all kinds of research institutions by providing training and organising events to present projects or initiatives such as conferences, science fairs and other outreach activities. Because of these activities, and also the fact that the Austrian Science Fund as the major funding organization for basic science in Austria, decided to continue the successful citizen science funding scheme "Top Citizen Science", we expect a further expansion of citizen science into fields currently underrepresented in the citizen science landscape in Austria, such as astronomy or arts. Additionally, the Federal Ministry for Education, Science and Research (BMBWF) has installed the "Center for Citizen Science" at the OeAD as a citizen science service point, indicating its support for citizen science in Austria.

Taking together all these activities, bottom-up and top-down initiatives and the potential of the method citizen science to make new research possible, we believe that citizen science will grow and will possibly make a big impact in the Austrian scientific community.

Mag. Dr. Daniel Dörler

ORCID: https://orcid.org/0000-0003-2056-4084 Universität für Bodenkultur Wien, Institut für Zoologie E-Mail: daniel.doerler@boku.ac.at

Dipl.-Ing. Dr. Florian Heigl ORCID: https://orcid.org/0000-0002-0083-4908 Universität für Bodenkultur Wien, Institut für Zoologie E-Mail: florian.heigl@boku.ac.at 


\section{References}

1 Eitzel, M.V.; Cappadonna, J.L.; Santos-Lang, C.; Duerr, R.E.;Virapongse, A.; West, S.E.; Kyba, C.C.M.; Bowser, A.; Cooper, C.B.; Sforzi, A.; Metcalfe, A.N.; Harris, E.S.; Thiel, M.; Haklay, M.; Ponciano, L.; Roche, J.; Ceccaroni, L.; Shilling, F.M.; Dörler, D.; Heigl, F.; Kiessling, T.; Davis, B.Y. and Jiang, Q. (2017). Citizen Science Terminology Matters: Exploring Key Terms. Citizen Science: Theory and Practice 2(1), 1-20. http:// doi.org/10.5334/cstp.96

2 Haklay M. (2013). Citizen Science and Volunteered Geographic Information: Overview and Typology of Participation. In: Sui D., Elwood S., Goodchild M. (eds). Crowdsourcing Geographic Knowledge. Springer, 105-122. https://doi.org/10.1007/978-94-007-4587-2_7

3 Sanz, F.S.; Holocher-Ertl, T.; Kieslinger, B.; García, F.S.; Silva, C.G. (2014). White Paper on Citizen Science for Europe; Socientize Consortium. http://www.socientize.eu/sites/default/files/white-paper_0.pdf

4 Heigl, F.; Kieslinger, B.; Paul, K.T.; Uhlik, J.; Dörler, D. (2019). Opinion: Toward an international definition of citizen science. Proceedings of the National Academy of Sciences 116(17), 8089-8092. https://doi. org/10.1073/pnas.1903393116

5 Wiggins, A.; Crowston, K. (2011). From Conservation to Crowdsourcing: A Typology of Citizen Science. In: Proceedings of the 2011 44th Hawaii International Conference on System Sciences, 1-10. https:// doi.org/10.1109/HICSS.2011.207

6 DITOs consortium (2017). Citizen Science \& Open Science: Synergies \& Future Areas of Work. Policy brief 3. https://ecsa.citizen-science.net/ sites/default/files/ditos-policybrief3-20180208-citizen_science_and_ open_science_synergies_and_future_areas_of_work.pdf

7 Nosek, B.A.; Alter, G.; Banks, G.C.; Borsboom, D.; Bowman, S.D.; Breckler, S.J.; Buck, S.; Chambers, C.D.; Chin, G.; Christensen, G. et al. (2015). Promoting an open research culture. Science 348(6242), 1422-1425. https://doi.org/10.1126/science.aab2374

8 Richter, A.; Dörler, D.; Hecker, S.; Heigl, F.; Pettibone, L.; Bonn, A. (2018). Capacity building in citizen science. In: Citizen Science - Innovation in Open Science, Society and Policy; UCL Press: London, UK, 269-283. https://doi.org/10.14324/111.9781787352339

9 Bonney, R. (1996). Citizen science: A lab tradition. Living Bird: For the Study and Conservation of Birds 15(4), 7-15.

10 Irwin, A. (1995). Citizen Science: A Study of People, Expertise and Sustainable Development; Routledge Chapman \& Hall. 
11 Dickinson, J.L.; Zuckerberg, B.; Bonter, D.N.(2010). Citizen Science as an Ecological Research Tool: Challenges and Benefits. Annual Review of Ecology, Evolution, and Systematics 41(1), 149-172. https://doi. org/10.1146/annurev-ecolsys-102209-144636

12 Dickinson, J.L.; Bonney, R. (2012). Citizen Science: Public Participation in Environmental Research; Cornell University Press.

13 Lepczyk, C.A.; Boyle, O.D.; Vargo, T.L.; Gould, P.; Jordan, R.; Liebenberg, L.; Masi, S.; Mueller, W.P.; Prysby, M.D.; Vaughan, H. (2009). Symposium 18: Citizen Science in Ecology: the Intersection of Research and Education. The Bulletin of the Ecological Society of America 90(3), 308-317. https://doi.org/10.1890/0012-9623-90.3.308

14 Miller-Rushing, A.; Primack, R.; Bonney, R. (2012). The history of public participation in ecological research. Frontiers in Ecology and the Environment 10(6), 285-290. https://doi.org/10.1890/110278

15 Heiss, R.; Matthes, J. (2017). Citizen Science in the Social Sciences: A Call for More Evidence. GAIA - Ecological Perspectives for Science and Society 26(1), 22-26. https://doi.org/10.14512/gaia.26.1.7

16 Paul, K.T. (2018). Collective organization of discourse expertise using information technology - CODE IT! it - Information Technology 60(1), 21-27. https://doi.org/10.1515/itit-2017-0022

17 Brauer, M. (2018). Opportunities and limitations of citizen science in the humanities. In: Proceedings of the Austrian Citizen Science Conference 2018 - Generation Citizen Science; Frontiers Media SA: Lausanne; 13-16. https://doi.org/10.3389/978-2-88945-587-4

18 Carletti, L.; Giannachi, G.; Price, D.; McAuley, D.; Benford, S. (2013). Digital humanities and crowdsourcing: an exploration. In: Museums and the Web 2013, N. Proctor \& R. Cherry (eds). Silver Spring, MD: Museums and the Web. https://mw2013.museumsandtheweb.com/ paper/digital-humanities-and-crowdsourcing-an-exploration-4/

19 Kasperowski, D.; Hillman, T. (2018). The epistemic culture in an online citizen science project: Programs, antiprograms and epistemic subjects. Social Studies of Science 48(4), 564-588. https://doi. org/10.1177/0306312718778806

20 Robinson, L.D.; Cawthray, J.L.; West, S.E.; Bonn, A.; Ansine, J. (2018). Ten principles of citizen science. Citizen Science - Innovation in Open Science, Society and Policy; UCL Press: London, UK, 27-40. https:// doi.org/10.14324/111.9781787352339

21 Heigl, F.; Dörler, D.; Bartar, P.; Brodschneider, R.; Cieslinski, M.; Ernst, M.; Fritz, S.; Greilhuber, I.; Hatlauf, J.; Hecker, S. et al. Quality Criteria for Citizen Science Projects on Österreich forscht | Version 
1.1. Open Science Framework 2018. https://doi.org/10.31219/osf. io/48j27

22 Clary, E.G.; Snyder, M. (1999). The Motivations to Volunteer: Theoretical and Practical Considerations. Current Directions in Psychological Science 8(5), 156-159. https://doi.org/10.1111/1467-8721.00037

23 Vicente-Saez, R.; Martinez-Fuentes, C. (2018). Open Science now: A systematic literature review for an integrated definition. Journal of Business Research 88, 428-436. https://doi.org/10.1016/j.jbusres.2017.12.043 24 Wilkinson, M.D.; Dumontier, M.; Aalbersberg, lj.J.; Appleton, G.; Axton, M.; Baak, A.; Blomberg, N.; Boiten, J.-W.; da Silva Santos, L.B.; Bourne, P.E. et al. (2016). The FAIR Guiding Principles for scientific data management and stewardship. Scientific Data 3, 160018. https:// doi.org/10.1038/sdata.2016.18

25 Dörler, D.; Heigl, F. (2018). Recent Developments in the Austrian Citizen Science Landscape. In: Proceedings of the Austrian Citizen Science Conference 2017 - Expanding Horizons; Frontiers Media SA: Lausanne, 5-7. https://doi.org/10.3389/978-2-88945-367-2

26 Heigl, F., Dörler, D., Weigelhofer, G., Hein, T., Zaller, J.G. (Eds.) (2016). Austrian Citizen Science Conference 2016: Citizen Science - Quo vadis?; Frontiers Media SA: Lausanne, 2016. https://doi.org/10.3389/978-288945-005-3

27 Heigl, F., Dörler, D., Ernst, M. (Eds.) (2018). Austrian Citizen Science Conference 2018; Frontiers Media SA: Lausanne. https://doi. org/10.3389/978-2-88945-587-4

28 Dörler, D.; Heigl, F.; Taru, S. (Eds.) (2018). Austrian Citizen Science Conference 2017 - Expanding Horizons; Frontiers Media SA: Lausanne. https://doi.org/10.3389/978-2-88945-367-2 